IJMS 17 (2), 27-46 (2010)

\title{
DRIVERS OF EFFICIENT SERVICE DELIVERY AND CALLER SATISFACTION: A MODEL OF CRM CUSTOMER CONTACT CENTRES IN MALAYSIA
}

\author{
ALIYU OLAYEMI ABDULLATEEF \\ SANY SANURI MOHD MOKHTAR \\ RUSHAMI ZIEN YUSUF \\ UUM College of Business \\ Universiti Utara Malaysia
}

\begin{abstract}
The benefits of CRM projects on business development has been a subject of discussion globally since 1990s. Evidence from different literature had equally established that there has been an increase in the attention paid to CRM by researchers, but to date, not much attempt has been made to develop a valid framework upon which the impact of CRM projects on the drivers of efficient service delivery and caller satisfaction in customer contact centre industry. This paper proposes a conceptual framework for measuring the drivers of efficient service delivery and caller satisfaction in customer contact centre. Given the need for more information that will assist in developing a viable theoretical framework for investigating service delivery in CRM contact centres, an exploratory pilot interview was conducted in four internationally recognised CRM customer contact centres that are based in Malaysia. The current results revealed a total of four major drivers of efficient service delivery (client factors, technology, process, and people), plus first call resolution as the determinant of caller satisfaction. Necessary recommendations as a guide for future research are also suggested.
\end{abstract}

Keywords: Customer relationship management (CRM); service delivery; caller satisfaction; contact centre.

\footnotetext{
Abstrak

Faedah projek pengurusan perhubungan pelanggan (CRM) ke atas pembangunan perniagaan telah dibincangkan di peringkat global sejak 1990-an lagi. Bukti daripada pelbagai ulasan karya telah menunjukkan
} 
peningkatan terhadap perhatian yang diberikan oleh para penyelidik kepada CRM. Bagaimanapun, sehingga hari ini, tidak banyak kajian yang dijalankan untuk membangunkan kerangka kerja yang melihat impak projek CRM ke atas pemandu kepada perkhidmatan pelanggan yang efisien dan kepuasan pemanggil di industri pusat perhubungan pelanggan. Kajian ini mencadangkan satu kerangka kerja konsepsual untuk mengukur pemandu kepada perkhidmatan pelanggan yang efisien dan kepuasan pemanggil di pusat perhubungan pelanggan. Berdasarkan kepada keperluan untuk mendapatkan lebih banyak maklumat yang boleh membantu untuk membangunkan kerangka kerja teorikal yang baik, kajian temu duga awal telah dilaksanakan di empat buah organisasi perkhidmatan perhubungan pelanggan yang terkenal di peringkat antarabangsa yang berpangkalan di Malaysia. Keputusan menunjukkan terdapat empat pemandu utama perkhidmatan pelanggan yang efisien (faktor-faktor pelanggan; teknologi; proses dan pekerja), termasuklah 'resolusi panggilan pertama' sebagai penentu kepada kepuasan pemanggil. Selain itu, beberapa cadangan diutarakan sebagai panduan kepada kajian pada masa hadapan.

\section{Introduction}

In the business world today, entrepreneurs have recognised that customers are the key element to any successful business. This is because both academic and practical research had proven that every business success depends greatly on the effectiveness of such companies in managing its relationships positively with the current and potential customers. Due to this unavoidable phenomenon, most entrepreneurs are making it a must to integrate their team of management and employees into knowing and practising the maxim "customers are always right" (Alison, 2009; Nguyen, Joseph \& Micheal, 2007). The term relationship can be interpreted as the process the organisations take in doing whatever they can to deliver on their promises to the customers more efficiently when compared to their competitors (Michael \& Adam, 2005; Kotler \& Armstrong, 2004; Evert, 2004; Dholakia, Morwitz \& Vicki, 2002). And maintaining these good relationships with the customers was further developed by adding the modern day automation processes to the existing CRM inputs (Riyad, 2007; Leo, Alan \& Frederick, 2005).

Customer Relationship Management (CRM) is a concept that derives its popularity since the 1990s. CRM is said to offer a long term changes and benefits to businesses that choose to adopt it. Different authors have argued that CRM enables companies to successfully interact with their customers in a dynamic and profitable manner (Aihie \& Az- 
Eddine 2007; Adam \& Michael, 2005; Evert, 2004). Whereas, up until today many scholars still debate over what should exactly constitute CRM; some argued that CRM is nothing more than mere software, while others described it as a modern means of satisfying customers' requirement with profit (Soon, 2007; Nguyen et al., 2007; Eric, Bedics \& Charles, 2006). While different researchers believed that there is no single acceptable definition of CRM, we would like to define CRM as the ability to efficiently integrate client's factors, people, process, and technology in maximising positive relationships with both current and potential customers (David \& Wendy, 2009; Coltman, 2007).

Between 1990s and now, CRM has gone through developmental stages where it has been transformed from an ordinary Web-based customer contact management and information gathering tools, to a real customer oriented strategic tool that has helped enhanced customer experience and automat processes in the global contact centre industry (Kyootai \& Kailas, 2007; Jon, 2000). Modern information technology inventions such as contact centre, online surveys, Webbased self services; mobile CRM solution, configuration support, and etc. have changed the history of CRM completely in the present millennium. All of these new inventions are mediums to efficiently search, communicate, share, and use information in economical ways that were not possible using the old system.

The availability of these modern information technologies has established growth in the importance of CRM call centre, which can directly be seen from the growth in numbers of call centre in recent days. Thus, this study was specifically designed to explore the interdependence of caller satisfaction and its drivers in CRM projects, by developing an alternative framework for measuring the impact of metrics such as client factors, technology, process, and people on efficient service delivery that impact caller's satisfaction in the contact centre industry.

\section{Theoretical Justification}

Global competition, and threatened by the financial crisis, has confirmed the need for service marketers to monitor how their customers feel about their services, and this can only be achieved by exploring every available means. For some years now, CRM as a new paradigm in marketing has revolutionised marketing thought with different applications (Nguyen et al., 2007; Riyad, 2007; Soon, 2007; Leo et al., 2005; Evert, 2004; James, 2004). Also in the contact centre 
industry, CRM is said to provide strategic advantages for companies by allowing fast and low cost contact to their current and potential consumers, when compared to face-to-face contact (Anand, 2008; Coltman, 2007; Soon, 2007; Adam \& Michael, 2005; Dholakia et al., 2002; Richard, Leigh, Rajah \& Iksuk, 2002).

However, going by the theoretical and practical arguments in favour of CRM as an important aspect of the existing marketing theories (David \& Wendy, 2009; Leo et al., 2005), with evidence of benefits accruing from investing in CRM (Riyad, 2007), combined with CRM's availability in today's market (Leo et al., 2005), notably CRM still continues to face different issues right from the conceptual stage right to the implementation and post implementation stage (David \& Wendy, 2009; Nguyen et al., 2007; Leo et al., 2005). A large percentage of CRM authors and some commercial research scholars have published relevant literature on the general implementations of CRM applications and technologies, with more specific focus on the impact of lack of commercial benefits that ought to be gained from substantive CRM investments (David \& Wendy, 2009). For every organisation that wishes to reap the full benefits of CRM technology implementations and adoptions, there is a need to be visible and establish a long-term senior management commitment with significant organisational change that is in accordance with the intended CRM system (Leo et al., 2005).

However it is argued by some scholars that the underlying expectation of any CRM technology to be implemented is to achieve customer loyalty and improve the corporate profitability, but contrary to this expectations, David and Wendy (2009) in their findings quoted a case study where well over " $55 \%$ of all the existing CRM projects don't produce the expected results" (David \& Wendy, 2009). Also in another survey of 1,500 companies conducted by The Data Warehousing Institute, the results showed that $91 \%$ of the companies have implemented CRM solution, whereas the results indicated that $41 \%$ of these companies with CRM projects have started to experience a series of implementation problems (The Data Warehousing Institute, 2000). The researchers would like to emphasise that given the extant literature reviews, CRM "successes" are not clearly defined both in IT or marketing literature. But as noted, this could partly be attributed to the difficulties that are inherent in the lack of globally accepted definition of CRM.

To further analyse the opinions and findings of researchers on the difference between perceptions and actual performance, many

30 IJMS 17 (2), 27-46 (2010) 
authors had proposed different instruments for measuring customer satisfaction in the service industry. Very famous among these instruments is SERVQUAL which was postulated by Parasuraman, Zeithaml, and Berry, (1985). Parasuraman (1998) and his team argued further that service quality is the existing gap between the expected and perceived service delivered by the service company. They denoted this gap as Gap 5 in the service quality gap model and argued that Gap 5 depends on the other four Gaps (Gap 1 to Gap 4) for achieving the expected service quality. Looking through what constitutes Gap 1 to Gap 5 on the service quality gap model, one will find out that the proposed conceptual framework for measuring efficient service delivery and caller satisfaction in this study captures Gap 3, which is service performance gap. Gap 3 is a gap that exists as a result of discrepancies between service quality specified by the service company and the actual service delivered. Among the primary reasons given by Parasuraman et al. (1985) in justifying the existence of Gap 3 are employee role ambiguity, employee role conflict, poor employee-job fit, poor technology-job fit, inappropriate evaluation and reward systems, lack of empowered service employees, and lack of teamwork.

Linking this to the studies that have been done in the call centre industry will bring us to the work of Ann, Patrick, and Frances (1999) in effective call centre management. They built a model to empirically examine the links among the various elements of the service delivery process in financial service firms starting from technology, process, and human resource, and ultimately established how each would impact service delivery. Their findings indicated a positive correlation among these variables and a strong effect each has on effective service delivery (Ann et al., 1999). Other studies such as Richard et al. (2002) had a different thing to say on the outcome of their study, where they found that none of the key elements were determinants of customer satisfaction in other customer contact centre are significant in the banking/financial call centre. They concluded that some of the things that were measured in the contact centre industry are simply not relevant and there is need for further research to look into it (Richard et al., 2002).

\section{Resourced Based Framework}

In order to fully present the theoretical framework upon which this study examined the operational tradeoffs and challenges that are

IJMS 17 (2), 27-46 (2010) 31 
inherent in the contact centre industry, and the impact that tactical and strategic CRM initiatives has on these tradeoffs, this research analysed the link between CRM and the customer contact centre industry from the point of Resource Based Theory. This is because CRM initiatives are nested within the organisation's system of interrelated and interdependent resources that companies use in generating competitive advantage (Coltman, 2007; Leo et al., 2005).

Several other authors have opined that Resource Based Theory categorises resources as those elements that are controlled by an organisation in order to formulate and implement necessary strategies that would assist in its operational efficiencies, such as people and technology (Leo et al., 2005; Meso \& Smith, 2000; Grant, 1996; Mahoney \& Pandian, 1992; Barney, 1991; Wernerfelt, 1984). Relationship Marketing in customer contact centre empirically aligned with the two schools of thought upon which Resource Based Theory is built, "Resource Based View (RBV)" and "Knowledge Based View (KBV)" where both emphasised on the benefits of organisational competitive advantages (Coltman, 2007; Acedo, Barroso \& Galan, 2006). In other words, CRM approach in customer contact centre is also empirically aligned with the aforementioned schools of thought.

Although service quality has been researched as a key driver of performance in the call center industry, but looking at it from the operational perspective, one would agree to the sustaining structures or resource-based tradeoffs and decisions that are inherent to deliver an efficient service to the current and potential customers. In this research, the researcher has presented this theoretical framework on resource-based arguments by introducing applicable concepts from resource-based theory, with evidence from operational perspectives such as capacity management and demand management, and how each has been effectively utilised to maximise labour and technology resources.

In the last two decades, the resource-based approach to company's competitive advantage has emerged as a strategic choice through which management of companies can identify, develop, and distribute key resources to maximise returns on investment (Meso \& Smith, 2000; Grant, 1996). Using this theoretical framework, this research used the extant literature and four case study examples to develop four variables that highlight the key resource management tradeoffs which significantly impact efficient service delivery and caller satisfaction in the customer contact centre industry. 


\section{Exploratory Investigation}

This exploratory study was deemed necessary given the existing facts that are known about service quality linkages in the contact centre industry, and the need for more information that will assist in developing a viable theoretical framework. In line with the argument of Alison (2009) who said that the what and how of the service delivery quality of contact centre could best be achieved through an appropriate exploratory study, this study had set the following research questions to determine the drivers of efficient service delivery and caller satisfaction in the customer contact centre industry.

Thus, this study mainly explored the four primary drivers of CRM Effectiveness in the customer contact centre industry. However, both the literature review and pilot interview established a causalities relationship between a contact centre's desired outcome of Efficient Service Delivery (CRM Effectiveness) and Caller Satisfaction (CRM Success). The researchers decided to use the word efficient because of the individual company resource constraint that in return determines the optimality of expected service delivery outcome. The researcher understood that each of this service delivery mix are maximised by companies subject to their available resource constraints, but making a joint utilisation of them efficiently will greatly impact the company and customer's expectations.

Although service quality has been extensively studied, the necessity to use exploratory study for this research is due to the insufficient academic literature on service delivery within the contact centre industry (Alison, 2009). However, in the course of advocating for a broader view of service quality has led the researchers into developing a detailed conceptual framework for investigating the concepts of service delivery in the CRM customer contact centre industry. A total of 16 executives of selected firms from four sectors (telecommunications-equipments, telecommunications-networks, transportation, and financial services) were interviewed with the following questions to explore the implementations and outcomes of CRM projects within these sectors of the contact centre industry as a strategic part of customer relationship marketing:

1. What do executives of customer contact centre believe to be the primary drivers of efficient service delivery?

2. How significant are client factors such as: client objectives, available resources, target market, top management commitment, etc. in determining efficient service delivery?

IJMS 17 (2), 27-46 (2010) 33 
3. What is the impact of CRM technology on efficient service delivery?

4. How relevant is CRM processes in achieving efficient service delivery?

5. What are those factors in CRM employee inputs that aid efficient service delivery?

6. Is there any interdependence among CRM service delivery inputs (client factors, technology, process, and people)?

7. Can there be a model that could be used in measuring the efficiency of service delivery from both client and customer perspectives in the customer contact centre Industry?

The above questions were conducted through an exploratory pilot interview in four internationally recognised CRM customer contact centre based in Malaysia. A total of 16 participants, four from each firm were interviewed on broad issues in service delivery and drivers of caller's satisfaction. Included in the list of those interviewed are senior vice president, operation managers, assistant managers, and agents. This research had screened the respondents to the above four groups mainly to reduce biasness and to make sure that they are directly involved in CRM service delivery operations. A remarkably consistent response emerged from the four sets of executives interviewed. Although some of their feedback were specific to company structure, all suggested that a general model of efficient service delivery in customer contact centre industry can be developed and implemented.

\section{The Research Model}

The study mainly explored the four primary drivers of efficient service delivery in the customer contact centre industry. Both the literature review and the pilot interview established a causalities relationship between a contact centre's desired outcome (efficient service delivery) and its primary drivers (efficient client factor, efficient technology, efficient process, and efficient people). This exploratory study decided to use the word efficient because of the individual company resource constraint that in return determines the optimality of expected service delivery outcome. The researcher understood that each of this service delivery mix are maximised by companies subject to their available resource constraints, but making a joint utilisation of them efficiently will greatly impact the company and customer's expectations. Please not that the measurement for the performance variables within the inbound contact centers such 
as first call resolution and caller satisfaction were based on industry practice. Specifically, call center managers will be asked to rate their company's performance based on the percentage of callers surveyed that report top box caller satisfaction and first call resolution (FCR) (Yim et al., 2005; Feirberg et al., 2002; 2000).

From the feedback of the exploratory study and relevant literature review, below is the proposed model (Figure 1). The analyses of the executives' responses are detailed under the elements of the model. Table 1 contains the constructs for measuring each element that constitute the drivers of efficient service delivery in the customer contact centre industry.

\section{A Service Delivery Model}

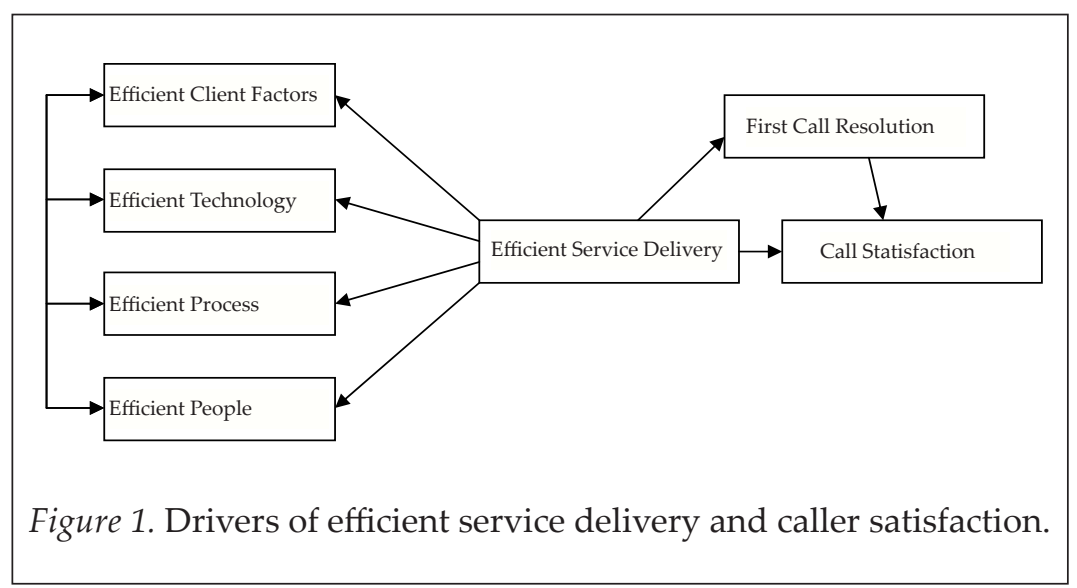

Table 1

Efficient Service Delivery Constructs in Customer Contact Center

\begin{tabular}{lll}
\hline & Items & Constructs \\
\hline 1. & Good product/Service quality & Efficient Client Factor \\
2. & Strong competitive strength & \\
3. & Well defined target market & \\
4. & Reasonable service objective & \\
5. & Enough available resources & \\
6. & Management support and commitment & \\
\hline
\end{tabular}

(continued)

IJMS 17 (2), 27-46 (2010) 35 


\begin{tabular}{|c|c|c|}
\hline & Items & Constructs \\
\hline 7. & $\begin{array}{l}\text { Good communication style between top } \\
\text { management and subordinate staff }\end{array}$ & \\
\hline 8. & $\begin{array}{l}\text { Presence of employee involvement in decision } \\
\text { making }\end{array}$ & \\
\hline 1. & Efficient voice response unit (VRU) & Efficient Technology Inputs \\
\hline 2. & Well designed interactive voice response (IVR) & \\
\hline 3. & Reliable internet and the corporate web sites & \\
\hline 4. & Presence of e-mail management software & \\
\hline 5. & Opportunity to telephone with toll free calls & \\
\hline 6. & $\begin{array}{l}\text { Efficient automatic call distributor and } \\
\text { predictive dialer }\end{array}$ & \\
\hline 7. & Efficient voice over internet protocol (VOIP) & \\
\hline 8. & Good value based caller routing & \\
\hline 9. & Presence of computer simulated training & \\
\hline 10. & Available computer telephony integration & \\
\hline 11. & Sufficient numbers of available lines & \\
\hline 1. & Minimal queue time & Efficient Process Inputs \\
\hline 2. & Reduced abandonment rate & \\
\hline 3. & Reasonable calls per period of time & \\
\hline 4. & Low percentage of calls blocked & \\
\hline 5. & Good staff scheduling & \\
\hline 6. & Well define average speed of answer & \\
\hline 7. & Well managed average talk time & \\
\hline 8. & Good service level & \\
\hline 1. & Efficient employee recruitment process & Efficient Employee Inputs \\
\hline 2. & Opportunity for employee empowerment & \\
\hline 3. & Good employee contextual knowledge & \\
\hline 4. & Lack of employee qualitative overstretch & \\
\hline 5. & Employee commitment & \\
\hline 6. & Well organized employee shift hour & \\
\hline 7. & Good remuneration package & \\
\hline 8. & Employee competence & \\
\hline 9. & Good employee communication style & \\
\hline 10. & Low level of employee turnover & \\
\hline
\end{tabular}

36 IJMS 17 (2), 27-46 (2010) 


\section{Elements of the Model}

\section{Caller Satisfaction}

Caller satisfaction is a component of overall customer satisfaction which could be describe as the psychological concept that captures the feelings of well-being and pleasure that results from customers' ability to obtain what they hope for and expect in calling the customer service department of their marketers/service providers (Eric et al., 2006; Roland \& Werner, 2005). Literature on the determinants of caller satisfaction is still at the infant stage when compared to the determinants of customer satisfaction. This is because caller satisfaction is limited in scope, specifically to call centre and the contact centre industry. Customer satisfaction on the other hand is wider and different approaches to its study has been in existence for decades.

Included in the scholarly works that have been done on customer satisfaction can be captured in the literature of Abraham and Taylor (1999). They reviewed all the related literature on customer satisfaction/dissatisfaction and came out with a comprehensive list of theories ranging from comparison-level, expectancy disconfirmation, assimilation or cognitive dissonance, assimilation-contrast, equity, attribution, generalised negativity, contrast, and value-precept.

The recent emphasis on efficient service delivery and first call resolution (FCR) as a key to caller satisfaction in the customer contact centre industry had illustrated the increased importance service providers/marketers are placing on customer quality and satisfaction. This is because a satisfied customer after contacting the contact centre is more likely to repurchase and promote positive world of mouth (Richard et al., 2002).

\section{Efficient Service Delivery}

The summary of feedback from the executive interviews was that, an efficient service delivery occurs when there is an efficient utilisation of service delivery inputs such as client's factor, people, process, and technology in meeting both customer expectations and client specifications. The executives believe that the presence of efficient service delivery will assist in reducing the effect of disconfirmation theory, which says the higher the difference in customer expectations and the perceived service performance, the greater the dissatisfaction 
of customer (Parasuraman, Berry \& Zeithaml, 1998). They gave practical examples of where the service delivery was excellent, but the customers were still dissatisfied due to their inability to achieve an immediate solution to the primary reasons of their calling.

In support of the above explanations, this study wishes to argue that the ability of a customer contact centre in achieving efficient service delivery will indicate its strengths in effective management of Gap 1 to Gap 3 as established by the disconfirmation of expectations paradigm in services marketing literature (Alison, 2009). Under the literature, Gap 1 discusses on the discrepancy between actual customer expectations and management perceptions of those expectations. This gap captures clients' inability to know what the customer expects, which could arise as a result of the following: lack of marketing research orientation, inadequate use of research findings, insufficient marketing research, and lack of interaction between management, employees, and customers (Dholakia et al., 2002; Parasuraman et al., 1985).

However the current findings of this research provided a different approach and suggested the need for an integration of some factors that are necessary in assessing service delivery in contact centre. Although Gap 2 analyses the discrepancies between management perceptions of customer expectations and service quality specifications, it is mainly about wrong service quality standards which could be as a result of any of the following: absence of goal setting, inadequate management commitment to service quality, and inadequate standardisation of task.

Meanwhile Gap 3 discusses about the discrepancy between service quality and service actually delivered. Gap 3 is nothing more than the service performance gap, which could arise as a result of any or a combination of the following: employee role ambiguity, employee role conflict, poor employee-job fit, poor technology-job fit, inappropriate evaluation and reward systems, lack of empowered service employees, and lack of teamwork (Dholakia et al., 2002; Parasuraman et al., 1985).

In essence, the efficient management of service delivery inputs will assist in preventing the occurrence of Gap 1 to Gap 3, and subsequently resulting in efficient service delivery that will positively impact caller satisfaction (Eric et al., 2006). But this is not excluding the impact of the initial product/service quality that has been rendered to the customers (Alison, 2009; Eric et al., 2006). The experiences of the 
existing customers on product/service qualities would directly or indirectly influence their satisfaction with the CRM customer contact centre services (Alison, 2009).

\section{First Call Resolution}

First Call Resolution (FCR) can be defined as the percentage of customers that do not need to call back in order to address their primary reason for calling. Different authors such as Feinberg et al. (2000), Roland and Werner (2005), Robinson and Morley (2006), Eric et al. (2006), and Levin (2007) have empirically argued in favor of FCR as the major determinant of caller satisfaction.

The result of the exploratory investigation on the customer contact service executive equally indicated a high significance of FCR as a major determinant of caller satisfaction. Also very important in their response was that FCR uniquely stands as a determinant of caller satisfaction differently from service delivery inputs. That is, a large portion of callers' reasons of dissatisfaction via interactive voice response are issues not resolved. This practically indicates that caller dissatisfaction could still exist despite the presence of efficient service delivery, but lack of FCR. Stephen and Michael (2007) in their review of call centre measurement have equally confirmed the significance of FCR by arguing that caller satisfaction will drop at an average of $15 \%$ in every callback a customer makes to the call centre, and that most of the top industry firms are defined in terms of those where their caller satisfaction ratings are at an average of $86 \%$ (Stephen \& Michael, 2007).

\section{Efficient Client Factors}

Despite the fact that each of the four interviewed firms have an established standard upon which they are delivering services to their customers, the executive interviews revealed that a combination of many factors in the client company under which the project is being implemented, whether in-sourced, outsourced, or co-sourced, would greatly affect the outcome of such project. Included but not limited to the client factors are: product/service quality, competitive strength, client objectives, available resources, management support and commitment, pattern of communication between top management and subordinates staff, and employee involvement in decision making will all, to a greater level, influence the performance of CRM projects in customer contact centre (Sarah \& Meredith, 2006). Also in this study, the interviewed employees argued that client objectives and available

IJMS 17 (2), 27-46 (2010) 39 
resources will determine the expected service level, operational processes to be implemented, number of agents to employ, salary to pay and training to be offered, and type of technology to implement. They concluded that the effectiveness of all these will determine the efficiency of service to be delivered to the customers.

\section{Efficient Technology}

The executive interview remarkably established that the strength of information technology has become significant means of favourable competition in the global market, particularly in the customer contact centre industry. Their arguments were based on the different opportunities in technology, which could assist in giving the required potentials for significant improvements in internal operational processes, personnel efficiency, and development in CRM projects. Included in their explanation was that CRM technologies are most useful when companies have large customer data. This is because it will bring efficiency to the management of customer information using information technologies and CRM software, such using as data warehousing. Hence, the reliability and effectiveness of the CRM technologies such as IVR, voice response unit, voice over internet protocol, predictive dialer, automatic call distributor, email software, etc. will positively impact the service to be delivered to customers (Richard et al., 2002).

Apart from the above, some of the executives had different things to say on technology acquisitions and implementations in call centre. They argued that although it is evident that technology is one of the key forces driving the competitive process of every modern day businesses, but making it too complex will negatively impact the customers and the internal users. Majority of the executives also indicated the need for understanding the implementation of the technology before embarking on it; their primary reason was that a business cannot efficiently compete on technology alone.

\section{Efficient Process}

Customer contact centre processes are strategically important to the performance measurement tools, which could be historically traced to easily identify the metrics, such as expected service level, expected call volume, speed of response, length of call, average hold time, calls per period, wrap-up time, queue time, abandonment rate, and the rest (Jon, 2000; Roland \& Werner, 2005); Timothy, Lerzan, Tor, Bruce \& Berry, 2006). Evidences from the focus interviews indicated

40 IJMS 17 (2), 27-46 (2010) 
that though it is easy to quantify these metrics, but their practical experiences have shown that they do not always represent sufficient percentage of what practically determines customer satisfaction.

They gave a practical example in support of their arguments, if an agent is to stick to the industry standard of keeping their call duration to the minimum, then what would be the likely outcome for callers who have many issues that they want to discuss in one call? Their argument on this is that if agents are given a goal of short call duration, they will do everything to meet this goal, and the consequences of setting such goal might lead to frustrated customers and lost of revenue. They concluded that effective management of the interaction between employees and other operational factors are good means of achieving CRM contact centre objectives.

\section{Efficient People}

The extant of marketing literature emphasised on the achievement of employee efficiency through a proactive management initiative in acquiring, training, motivating, empowering, and supporting their employees (Roland \& Werner, 2005; Mohr, 1998). Within the customer contact centre industry, employee efficiency could be attained through the presence of implemented feedback procedures, training of skills, and empowerment of the employees on decision-making processes within the firm (Roland \& Werner, 2005). Kode, Martin, and Richard (2001) investigated which forms of management styles will decrease role stress and subsequently increase job satisfaction; their findings indicated that autonomy empowerment has a positive effect on employee job satisfaction and commitment. And employees being the first contact point in the customer contact centre industry will greatly impact customer ability in getting their issues resolved within their first call.

As supported by the executives in the pilot study, the people are the key element in the service delivery inputs that need proper management, because they serve as the first touch point between the customer and the contact centre. Some of the feedback from the interviewed executives indicated that the performance of the employee centred more on the following key areas: efficient employee recruitment process, opportunity for empowerment, lack of qualitative overstretch, well organised shift hour, good remuneration package, and commitment. They argued that the management of the aforementioned is a must for any focused contact centre manager, because the larger percentage of customer perceptions of the company

IJMS 17 (2), 27-46 (2010) 41 
is managed by the employees, and that effective management of the employees will positively impact the company's image on its internal and external customers.

They finally emphasised that a satisfied employee will be committed and encouraged to use everything in detecting the inefficiencies in the service delivery process of the whole organisation. Alison (2009) also emphasised on the need to achieve an efficient call centre employee as strategic means to attaining the high standard of service quality that is set by the management.

\section{Discussions and Conclusions}

The above proposed model is a conceptual framework through which the drivers of efficient service delivery and callers satisfaction could be measured. It is empirically based on the existing literature on customer contact centre and the interpretation of data generated from the exploratory study which were conducted through a series of pilot interviews with customer contact centre executives. Relevant information on which variables drive efficient service delivery and caller satisfaction will not only assist in day-to-day decision making in the contact centre, but will contribute significantly to cost reduction and employee retention. This study has revealed the four primary drivers of efficient service delivery, plus first call resolution as the determinant of caller satisfaction in the CRM customer contact centre industry.

For the first time in the history of CRM customer contact centre literature, this research has provided a detailed breakdown of the inputs that drives each drivers of efficient service delivery in Table 1. The researchers believed that the proposed conceptual service delivery model in this study will, to a great level, provide opportunities for both academic and practitioners in their future activities. Specifically for the contact centre firms, this study will assist in establishing an industry standard and also provide feedback on the returns of their investments on relationship strategies. For the academician, while complementing on the existing service marketing theories, this study will equally be very useful in developing alternating theories and models that will facilitate the general operations of the customer contact centre industry.

Given the findings in this study, the researchers outlined the following key areas that could be of interest to future researchers in the field of customer contact centre. Firstly, there is need for a 
research on additional variables such as caller's inputs (education, culture, age, and buying behaviour) that might directly or indirectly influence customer's level of satisfaction. Secondly, client factors are very significant in the acquisition and management of technology, processes and people, whether in-source, outsource, or co-source. There is a need for research that will assist in structuring the acquisition of technology, process, and people based on the existing client factors.

Thirdly, people's attrition is a very hot issue in the modern day CRM customer contact center. There is a greet need for research that will guide on restructuring the recruitment process right from job description, job analysis, behavioural interview, employee orientation, job placement, and follow-up training. Fourthly, the researchers observed that lack of detailed knowledge of customer's feelings on specific technology before its implementation has resulted in some companies' failure; complex technologies resulting in dissatisfied customers. In view of this, there is a need for immediate research on how to incorporate Technology Readiness Index (TRI), propounded by Parasuraman (2000) into the operations of the customer contact centre industry.

Finally, there is a need for research to look into the impact of the multifactor processes (speed of response, length of call, average hold time, calls per period, and wrap-up time) on agent performances. Are they a positive influence on agent's performance in achieving customer satisfaction? And if otherwise, what specific process inputs positively impact agent's performance will be a very useful guide for contact center managers?

\section{References}

Abraham, P., \& Taylor, E. (1999). Customer satisfaction and its measurement in hospitality enterprises. International Journal of Contemporary Hospitality Management, 11(7), 326-339.

Acedo F. J., Barroso, C., \& Galan, J. L. (2006). The resourced based theory: Disseminations and main trends. Strategic Management Journal, 621-636.

Adam, L., \& Michael, A. (2005). Customer relationship management: The case of a European bank. Marketing Intelligence and Planning, 23(2), 136-154.

Aihie, O., \& Az-Eddine, B. (2007). An exploratory study of implementation of customer relationship management strategy. Business Process Management Journal, 13(1), 139-164.

IJMS 17 (2), 27-46 (2010) 
Alison, M. D. (2009). Frontline employees' views on organisational factors that affect the delivery of service quality in call centre. Journal of Service Marketing, 23/5, 326-337.

Anand, K. J. (2008). Customer satisfaction and service quality measurement in Indian call centres. Managing Service Quality, 18(4), 405-414.

Ann, E., Patrick, T. H., \& Frances, X. F. (1999). Effective call center management: Evidence from financial services. The Wharton School, University of Pennsylvania.

Barney, J. B. (1991). Firm resources and sustained competitive advantage. Journal of Management, 17(1), 99-120.

Coltman, T. R. (2007). Can superior CRM capabilities improve performance in banking. Journal of Financial Services Marketing, 12(2), 102-114.

David, J. F., \& Wendy, L. C. (2009). A multi-layered approach to CRM implementation: An integration perspective. European Management Journal.

Dholakia, U., Morwitz, M., \& Vicki, G. (2002). The scope and persistence of mere-measurement effects: Evidence from a field study of customer satisfaction measurement. Journal of Consumer Research, 29(2), 159-67.

Eric, P. J., Bedics, T. A., \& Charles, E. M. (2006). Operational challenges in call centre industry: A case study and resourse based framework. Managing Service Quality Journal, 477-500.

Evert, G. (2004). Return on relationships (ROR): The value of relationship marketing and CRM in business-to-business contexts. Journal of Business and Industrial Marketing, 19(2), 136148.

Feinberg, R. A., Kim, I. S., Hokama, L., de Ruyter, K., \& Keen, C. (2000). Operational determinants of caller satisfaction in the call center. International Journal of Service Industry Management, 11(2), 31-41.

Grant, R. (1996). Toward a knowledge based theory of the firm: Strategic Management Journal, 38(5), 109-122.

James E. R. (2004). CRM B2B implementation, an exploratory study. Victoria University of Wellington.

Jon, A. (2000). The past, present, and future of customer access centres. International Journal of Service Industry Management, 120-130.

Kode, R., Martin W., \& Richard F. (2001). Role stress in call centers: Its effect on employee performance and satisfaction. Journal of Interactive Marketing, 15(2), 23-33.

Kotler, P., \& Armstrong, G. (2004). Principles of marketing (10th ed.). Pearson: Prentice Hall.

44 IJMS 17 (2), 27-46 (2010) 
Kyootai, L., \& Kailas, J. (2007). Customer satisfaction with technology mediated service encounter. Journal of Information Technology Management, Volume XVIII, (2).

Leo, Y. S., Alan C. T., \& Frederick, H. Y. (2005). CRM: Conceptualisation and scale development. European Journal of Marketing, 39(11/12), 1264-1290.

Mahoney, J. T., \& Pandian J. R. (1992). The resource based view within the conversation of strategic management. Strategic Management Journal, 13, 363-380.

Meso, P., \& Smith, R. (2000). A resource based view of organizational knowledge management systems. Journal of Knowledge Management, 4(3), 224-231.

Mohr, J. I. (1998). Conceptualising total quality orientation. European Journal of Marketing, 32(2), 13-22.

Nguyen, T. H., Joseph, S. S., \& Michael, N. (2007). Strategies for successful CRM implementation. Journal of Information Management and Computer Security, 15(2), 102-115.

Parasuraman, A., Berry, L. L., \& Zeithaml, V. A. (1988). SERVQUAL: A multiple-item scale for measuring consumer perceptions of service quality. Journal of Retailing, 64(1), 12-40.

Parasuraman, A. (1998). Customer service in business-to business markets: An agenda for research. Journal of Business and Industrial Marketing, 13(4/5), 309-321.

Parasuraman, A., Zeithaml, A. V., \& Berry, L. L. (1985). Problems and strategies in service marketing. Journal of Marketing, 49(2), 3346.

Parasuraman, A. (2000). Technology readiness index (tri): A multipleitem scale to measure readiness to embrace new technologies. Journal of Service Research, 2(4), 307-320.

Richard, A. F., Leigh, H., Rajesh, K., \& IkSuk, K. (2002). Operational determinants of caller satisfaction in the banking/financial services call center. International Journal of Bank Marketing, 174180.

Riyad, E., (2007). Towards a successful CRM implementation in banks: An integrated model. The Service Industry Journal, 27(8),10211039.

Roland, K., \& Werner, H. K. (2005). Managing overall service quality in customer care centres. International Journal of Service Industry Management, 135-151.

Sarah, S. M., \& Meredith, L. (2006). Improving customer service: Issues in customer contact management. European Journal of Marketing, 40(1/2), 218-232.

Stephen, J., \& Michael, B. (2008). A review of call centre measurements. Nova Southeastern University, USA.

IJMS 17 (2), 27-46 (2010) 45 
Soon, H. S. (2007). An empirical analysis on the operational efficiency of CRM call centres in Korea. Call center Industry Research Center.

The Data Warehousing Institute. (2000). Executive summary on harnessing customer information for strategic advantage: Technical challenges and business solutions. Retrieved from http: www.dwinstitute.com

Timothy, L. K., Lerzan A., Tor, W. A., Bruce C., \& Barry J. W. (2006). Call centre satisfaction and customer retention in a co-branded service context: Managing Service Quality, 269-289.

Wernerfelt, B. (1984). A resource based view of the firm. Strategic Management Journal, 5, 171-180. 